\title{
Genetically modified crops and food
}

\author{
Zorica Nikolić1, Gordana Petrović1, \\ Maja Ignjatov' ${ }^{1}$, Dragana Milošević1, \\ Dušica Jovičić1, Gordana Tamindžić \\ ${ }^{1}$ Institute of field and vegetable crops, \\ National Institute of the Republic of Serbia, \\ Maksima Gorkog 30, 21000 Novi Sad \\ Corresponding author: \\ Dr Zorica Nikolić \\ Institut za ratarstvo i povrtarstvo, Novi Sad \\ Tel.: 0214898 150; Fax: 021421249 \\ E-mail address: zorica.nikolic@ifvens.ns.ac.rs
}

\begin{abstract}
Global resources are being invested heavily for research and development involving new genetic modification technologies. Growing genetically modified (GM) crops has opened up a debate on the safety of GM crops and the potential long-term harmful effects on the environment, human health and sustainability of new technologies. Food that contains some of the GM ingredients is progressively present on the world market. National legislations differ in countries around the world, from the complete ban on GM foods, to propaganda and acceptance without marking. In our country, according to current regulations, import raw materials for the food industry are controlled for the presence of genetic modification. In order to protect consumers and food safety, it is necessary to monitor the presence of genetic modification at key points in production, from primary production, through processing to market placement.
\end{abstract}

Keywords: genetic modification, crops, food.

\section{UVOD}

Pre više od 20 godina, jedna od ideja molekularne genetike bila je stvaranje poboljšanih biljnih vrsta kako bi se nahranila narastajuća ljudska populacija. U proteklom periodu u biljke su uneti geni za: poboljšanje agronomskih osobina (otpornost prema štetnim insektima, prouzrokovačima biljnih bolesti, virusima, bakterijama, tolerantnost na totalne herbicide i dr.); poboljšanje kvaliteta proizvoda (povećan sadržaj proteina, ulja i sl.); proizvodnju specifičnih proteina (vakcine i antitela).

Prema podacima iz 2017. godine genetički modifikovane biljne vrste gajene su u dvadeset četiri zemlje u svetu na oko 190 miliona hektara [1]. U Evropskoj Uniji (EU) površine pod GM usevima su u odnosu na površine pod konvencionalnom i organskom proizvodnjom zanemarljive. Genetički modifikovan kukuruz se u 2007. gajio u 6 zemalja EU (Španija, Francuska, Češka Republika, Portugal, Nemačka, Slovačka), dok ga posle deset godina samo Španija i Portugal gaje na oko 131.535 ha i koriste za proizvodnju biogoriva i ishranu stoke. Jake kampanje protiv GM useva kao i zahtevi mlinarske industrije za ne GM kukuruzom, dovele su do toga da se potrebe za GM kukuruzom zadovoljavaju uvozom [1]. U Srbiji nije dozvoljeno komercijalno gajenje GM useva.

U poslednjih 15 godina nekoliko kritičnih situacija u vezi sa hranom ozbiljno su narušile poverenje javnosti u proizvođače hrane i njihove kapacitete u proizvod- nji sigurne hrane, a sigurnost hrane, uključujući' i GM hranu, postala je glavni prioritet evropskih zakonodavnih vlasti [2]. U okviru Evropske unije, važeći zakoni i propisi o sledljivosti i označavanju zahtevaju obavezno označavanje hrane i hrane za životinje koja sadrži GM sastojke iznad 0,9\%, identifikaciju GM proizvoda u celom lancu snabdevanja, kao i nultu toleranciju prema nedozvoljenim GM u hrani, a 0,1\% nedozvoljenim GM u stočnoj hrani [3]. U budućnosti se ne očekuje da će biotehnološki usevi u većoj meri biti usvojeni u EU, mada postoje pokreti među poljoprivrednim proizvođačima, istraživačima i regulatornim sektorima koji ukazuju na moguće promene u prihvatanju i percepciji.

\section{Genetički modifikovana soja}

Roundup Ready (RR) soja (GTS 40-3-2) ili soja tolerantna na herbicid glifosat, najčešća je transgena linija soje, jedna od sedam transgenih linija koje su dozvoljene za tržište EU. Ni jedna od tih linija nije dozvoljena za gajenje. RR soja se gaji na $83 \%$ ukupnih površina pod sojom u svetu, a tokom godina gajenja potpuno je uključena u lanac hrane i hraniva [4]. Svake godine EU uvozi oko 18 miliona tona soje i 20 miliona tona sojine sačme iz Brazila, SAD-a i Argentine, uglavnom sojino brašno i sirova biljna ulja, ali i druge proizvode od soje.

Najozbiljniji problem za poljoprivrednike koji uzgajaju RR soju je pojava korova otpornih na glifosat, ili „superkorova”. Korovi su se javili u regionima gde su 
gajeni usevi otporni na glifosat i kao posledica prekomerne upotrebe ovog herbicida [5], a nađena je 21 korovska vrsta sa glifosat rezistentnim genotipovima [6]. Povećana otpornost na herbicide može da dovede do povećanja primene selektivnih širokolisnih herbicida ili smeša herbicida. Poznato je da se herbicidi akumuliraju u plodovima i krtolama i da oni malo degradiraju kroz metaboličke procese u biljci, te se sa ovom preteranom upotrebom herbicida pojavljuju pitanja o bezbednosti hrane [7].

Primena herbicida sa odloženim dejstvom, koji su mobilni u površinskim vodama ili prodiru u podzemne vode, može dovesti do dodatnih problema kvaliteta vode. Toksičnost glifosata povećana je dodatim sastojcima i surfaktantima koji olakšavaju prijanjanje herbicida na lišće i prodor u ćelije biljke, kako bi se transportovali do svih delova biljke. Glifosat se razlaže u prirodnom okruženju i formira aminometilfosfonsku kiselinu (AMPA), koja je veoma slična po hemijskoj strukturi glifosatu. Postoje dokazi da AMPA takođe može imati uticaj na životinje i zdravlje ljudi i životnu sredinu [8].

\section{Genetički modifikovani usevi u Srbiji?}

Gajenje genetički modifikovanih biljaka pokrenulo je brojne polemike u Srbiji, oko njihovog uticaja na sredinu u ekološkom smislu i njihovom ekonomskom uticaju. lako se smatra da nema razlike između GM useva i konvencionalnih useva, kao i dokumentovanih dokaza o riziku po zdravlje ljudi ili životnu sredinu [9], postoji zabrinutost o mogućim neželjenim efektima genetičke modifikacije na ljudsko zdravlje i okruženje [10]. Pored toga, postoji zabrinutost da će trgovina GM semenom rezultirati širenjem GM useva u zemljama u kojima oni nisu odobreni [11]. Evropska unija nastavlja da bude region u kome je komercijalno gajenje genetički modifikovanih useva veoma ograničeno.

U organskoj poljoprivredi propisi ne dozvoljavaju upotrebu genetičkog inženjeringa u sistemu proizvodnje žitarica u cilju garantovanja potrošačima proizvoda bez GM. Udeo GM u semenu ne može preći određen nivo, npr. $0,1 \%$, ako se radi o organskom usevu i organskom semenu. Ovo uključuje sve izvore transgene kontaminacije tokom proizvodnje i distribucije, što je zbog posebnih distributivnih linija generalno nisko u organskim usevima [12]. Srbija je, zahvaljujući tradicionalnom uzgajanju soje, jedna od pet najvećih proizvođača u Evropi. Osvajanju tržišta je doprinela činjenica da se soja kod nas uzgaja konvencionalno, bez prisustva genetički modifikovanih organizama.

Zemlje dunavskog regiona su 2012. godine osnovale međunarodno udruženje Dunav Soja, koje sada ima preko 290 članova, važnih učesnika tržišnog lanca vrednosti, iz 21 evropske zemlje. Osnovni cilj udruženja je proizvodnja visokokvalitetne hrane bez GM, unapređenje i promovisanje proizvodnje, prerade i plasmana genetički nemodifikovane soje iz Evrope.

\section{Stavovi potrošača o GM hrani}

Većina evropskih potrošača prilično su skeptični kada je u pitanju GM hrana, a u poređenju sa drugim rizicima u hrani, GM hrana nije na visokorangiranom mestu [13]. Stavovi potrošača uzimaju u obzir mnoge faktore, uključujući informacije, poverenje, uverenja, percepcije rizika i koristi, a razvijaju se na pozadini složenog skupa ličnih vrednosti koje u velikoj meri predodređuju kako se informacije obrađuju i ocenjuju [14].

U jednoj marketinškoj studiji identični plodovi voća bili su označeni kao „organski”, ,"konvencionalni” ili „,bez GM" i prodavali su se na štandovima pored puta u Nemačkoj, Švedskoj, Francuskoj, Belgiji i Velikoj Britaniji. Kada su cene za sve proizvode bile identične potrošači su preferirali organske proizvode, mada su „plodovi bez GM-a" postigli tržišni udeo oko $20 \%$. Kada je cena "organsko" voće povećana za $15 \%$, a cena voća „bez GM“ snižena za $15 \%$, udeo biotehnoloških plodova u prodaji povećao se na 43\% u Švedskoj, 33\% u Francuskoj, 30\% u Velikoj Britaniji i 36\% u Nemačkoj [14]. Studija preferencije putem upitnika je pokazala da bi samo $12 \%$ ispitanika u Nemačkoj kupilo biotehnološko voće, a 31\% u Švedskoj [15].

U Turskoj je Udruženje proizvođača i uzgajivača mesa peradi dobilo dozvolu za uvoz 36 genetičkih modifikacija soje, kukuruza, uljane repice i pamuka koji će koristiti $u$ industriji hrane i hrane za životinje, što znači da je Turska prihvatila biotehnološke proizvode [16]. Prema važećem Zakonu meso se ne testira na prisustvo GM, a meso uvozimo iz npr. Argentine koja je veliki proizvođač mesa, a u isto vreme i proizvođač GM soje i kukuruza [17]. Najnoviji izvještaji pokazuju da poljoprivredna industrija ulaže oko 69 milijardi dolara na globalnom nivou za istraživanja i razvoj koja uključuju istraživanja novih tehnologija GM useva [18].

\section{Monitoring hrane na prisustvo genetičke modifikacije}

Proces proizvodnje prehrambenih proizvoda često obuhvata različite postupke obrade, tako da se potencijalni GM sastojci, DNK ili protein, u gotovom proizvodu više ne mogu detektovati, a posebno u visokorafinisanim proizvodima kao što su skrob, lecitin, biljna ulja. Pouzdano određivanje sadržaja GM u proizvodima zavisi od efikasnosti ekstrakcije DNK iz uzorka. Studija koju su sproveli Nikolić i sar. pokazala je da je procenat GM u sirovo ceđenom ulju soje odgovara sadržaju GMO u semenu soje [19]. U procesu proizvodnje tofua, mehanička i temperaturna manipulacija uzrokuje degradaciju DNK i utiče na efikasnost PCR-a i rezultate GMO sadržaja u gotovom proizvodu [20].

$\mathrm{U}$ prehrambenim proizvodima sa teritorije opštine Novi Sad, uzetim po metodi slučajnog uzorka iz prodavnica zdrave hrane, koji su u svom sastavu imali soju ili kukuruz, uključujući i uzorke dečje hrane, nisu nađeni proizvodi koji sadrži više od 0,9\% GMO [21]. 
Proteini, ali i druge komponente iz soje i kukuruza obavezan su sastojak mesnih proizvoda. Uzorci mesnih proizvoda različitih proizvođača, na tržištu grada Novog Sada, sadržali su manje od 0,9\% genetičke modifikacije [22]. Takođe, analiza 100 uzoraka vegetarijanske i hrane iz prodavnica zdrave hrane, koji su sadržali kukuruz i pirinač, pokazala je da nisu prisutne genetičke modifikacije [23].

Monitoring uzoraka hrane za životinje domaćih proizvođača sproveden 2010. godine, pokazao je da je $46 \%$ uzoraka imalo visok sadržaj GMO soje. Proizvodi nisu bili obeleženi, a proizvođači nisu bili upoznati sa obavezom testiranja hrane za životinje na prisustvo genetičke modifikacije [24]. Međutim, zakon ne reguliše proizvode životinjskog porekla dobijene od životinja hranjenih GM stočnom hranom i sojom, što je slučaj u 90 odsto stočarske proizvodnje u Evropi.

Rezultati sprovedenih studija ukazali su na potrebu kontinuiranog monitoringa hrane i hraniva, na prisustvo genetičke modifikacije, kao i proveru postojanja GM semena na različitim tačkama na putu od polja preko postrojenja za preradu hrane do gotovog proizvoda [25].

\section{ZAKLJUČAK}

Mada su ukupne površine pod GM usevima u svetu u porastu, tehnologija genetičke modifikacije suočava se sa značajnim otporom u Evropskoj uniji tako i u našoj zemlji, uglavnom zbog mogućih dugoročnih negativnih uticaja na životnu sredinu i zdravlje ljudi. Praktično je nemoguće izračunati ili predvideti dugoročne posledice koje proističu iz široke upotrebe GM useva. Srbija ima veoma povoljne prirodne uslove za raznovrsnu poljoprivrednu proizvodnju, iskusne proizvođače i vrhunske stručnjake koji su razvili optimalne tehnologije oslanjajući se na tradicionalne metode i postupke. Domaće sorte i hibridi predstavljaju nacionalno blago jedne države, a nove genetički modifikovane sorte ne znače bolji kvalitet od onoga što mi imamo.

\section{LITERATURA}

1. James C. Global Status of Commercialized Biotech/GM Crops: 2017. ISAAABrief No.53. ISAAA: Ithaca, NY.

2. Varzakas TH, Arvanitoyannis IS, Baltas H. The Politics and Science behind GMO Acceptance. Crit Rev Food Sci Nutr 2007;47:335-61.

3. Uredba (EZ) br. 1829/2003 Evropskog parlamenta i veća

4. James C (2011): Global Status of Commercialized Biotech/ GM Crops: 2017. ISAAABrief No.43. ISAAA: Ithaca, NY.

5. Mortensen DA, Egan JF, Maxwell BD, Ryan MR, Smith RG. Navigating a Critical Juncture for Sustainable Weed Management. BioSci 2012;62(1):75-84.

6. Heap I. International Survey of Herbicide Resistant Weeds. Weed-Science.org (12 October 2011; www.weedscience.org)
7. Altieri M. The ecological impacts of transgenic crops on agroecosystem health. Ecosyst Health 2000;6(1):13-23.

8. Abouziena HFH, Sharma SD, Singh M. Impact of adjuvants on bentazon efficacy on selected broadleaf weeds. Crop Prot 2009;28:1081-5.

9. Paarlberg R. GMO foods and crops: Africa's choice. New Biotechnol 2010; 27(5):609-13.

10. Falck-Zepeda JB. Socio-economic considerations, Article 26.1 of the Cartagena protocol on Biosafety: What are the issues and what is at stake? Ag Bio Forum 2009;12(1):90107.

11. Clapp J. Illegal GMO releases and corporate responsibility: Questioning the effectiveness of voluntary measures. Ecol Econ 2008;66:348-58.

12. Damgaard C, Kjellsson G. Gene flow of oil seed rape (Brassica napus) according to isolation distance and buffer zone. Agric Ecosyst Environ 2005;108:291-301.

13. Desaint $\mathrm{N}$, Varbanova $\mathrm{M}$. The use and value of polling to determine public opinion on GMOs in Europe: Limitations and ways forward. GM Crops Food. 2013;4:183-94.

14. Lucht JM. 2015. Public acceptance of plant biotechnology and GM crops. Viruses 7(8):4254- 4281. https://www. ncbi.nlm.nih.gov/pmc/ articles/PMC4576180/.

15. Knight JG, Mather DW. Holdsworth DK. Ermen DF. Acceptance of GM food -An experiment in six countries. Nat Biotechnol 2007;25:507-8.

16. Turkey approves four more biotech traits [internet]. ISSA, Crop Biotech Update, (9. Avgust2017.) http://www.isaaa. org/kc/cropbiotechupdate/article/default.asp?ID=15668

17. Službeni glasnik RS 41/2009 Zakon o genetički modifikovanim organizmima.

18. Smyth S. Genetically modified crops, regulatory delays, and international trade. Food and Energy Security. 2017;6(2):78-86.

19. Nikolić Z, Vasiljević I, Zdjelar G, Đorđević V, Ignjatov M, Jovičić $D$, Milošević $D$. Detection of genetically modified soybean in crude soybean oil. Food Chem 2014;145:1072-5.

20. Nikolić $Z$, Petrović $G$, Panković $D$, Ignjatov M, Marinković $D$, Stojanović M, Đorđević ]. Threshold level and traceability of Roundup Ready soybean in practice of producing tofu. Food Tech Bio 2017;55(4):439-44.

21. Nikolić Z, Milošević $M$, Taški $K$, Vujaković $M$, Zlokolica $M$. Monitoring prehrambenih proizvoda na prisustvo genetske modifikacije. Agroznanje 2005;6(3):91-8.

22. Taški-Ajduković $K$, Nikolić Z, Vujaković $M$, Milošević $M$, lgnjatov $M$, Petrović $D$. Detection of genetically modified organisms in processed meat products on the Serbian food market. Meat Sci 2009;81:230-2.

23. Zdjelar G, Nikolić Z, Vasiljević I, Bajić B, Jovičić D, Ignjatov $M$, Milošević $D$. Detection of genetically modified soya, maize and rice in vegetarian and healthy food products in Serbia. Czech J Food Sci 2013;31(1):43-8.

24. Nikolić Z, Vujaković M, Vasiljević S, Bokan N, Karagić Đ. Occurence of Roundup ready soybean in serbian feed products. Biotechnol Anim Husb 2010;26:619-26.

25. Nikolić $Z$, Taški-Ajduković $K$, Tatić $M$, Balešević-Tubić $S$. (2009): Monitoring of the Roundup Ready soybean in the Vojvodina province in Serbia. Industrial Crops and Products 2009;29:638-41. 


\section{Genetički modifikovani usevi i hrana}

\author{
Zorica Nikolić1, Gordana Petrović1, Maja \\ Ignjatov ${ }^{1}$, Dragana Milošević ${ }^{\text {, Dušica }}$ \\ Jovičić ${ }^{1}$, Gordana Tamindžić ${ }^{1}$ \\ 'Institut za ratarstvo i povrtarstvo, \\ Maksima Gorkog 30, 21000 Novi Sad
}

\begin{abstract}
Kratak sadržaj
Za istraživanja i razvoj novih tehnologija proizvodnje genetičkih modifikacija se na globalnom nivou ulažu ogromna sredstva. Gajenje genetički modifikovanih (GM) biljaka otvorilo je veliku debatu o bezbednosti GM useva i mogućih dugoročnih štetnih uticaja na životnu sredinu, zdravlje ljudi i održivost novih tehnologija. Hrana koja sadrži neki od sastojaka koji je GM je sve više prisutna na svetskom tržištu. Nacionalna zakonodavstva se razlikuju u zemljama u svetu, od potpune zabrane GM hrane, do propagiranja i prihvatanja bez obeležavanja. U našoj zemlji se, prema važećim propisima, uvozne sirovine za prehrambenu industriju kontrolišu na prisustvo genetičke modifikacije. U cilju zaštite potrošača $i$ bezbednosti hrane neophodan je monitoring na prisustvo genetičke modifikacije na ključnim tačkama u proizvodnji, od primarne proizvodnje, preko prerade do plasmana na tržištu.
\end{abstract}

Ključne reči: genetička modifikacija, usevi, hrana. 